\title{
Food and Water Consumption End Date Time
}

National Cancer Institute

\section{Source}

National Cancer Institute. Food and Water Consumption End Date Time. NCI Thesaurus.

Code C119829.

The date and time a food and water consumption assessment has concluded. 